\section{Intersections}

Canadian Journal of Music

Revue canadienne de musique
Intersections

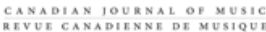

\title{
Expanding the University Music Ensemble: Lessons from an Intercultural Collaboration
}

\section{Linda Pearse}

Volume 39, numéro 1, 2019

Decolonizing Music Pedagogies

URI : https://id.erudit.org/iderudit/1075340ar

DOI : https://doi.org/10.7202/1075340ar

Aller au sommaire du numéro

Éditeur(s)

Canadian University Music Society / Société de musique des universités canadiennes

ISSN

1918-512X (numérique)

Découvrir la revue

Citer cet article

Pearse, D. L. (2019). Expanding the University Music Ensemble: Lessons from an Intercultural Collaboration. Intersections, 39(1), 21-40.

https://doi.org/10.7202/1075340ar
Résumé de l'article

Les universités sont de plus en plus conscientes de la nécessité de revoir les programmes d'études afin de prendre en compte les perspectives, les connaissances et les approches pédagogiques autochtones. Les programmes universitaires en musique, axés sur l'enseignement du corpus de musiques occidentales savantes, ont souvent du mal à mettre en oeuvre un engagement réel et significatif avec les connaissances autochtones. Quelles mesures concrètes les enseignants peuvent-ils prendre pour aller au-delà de l'enseignement du canon limité par l'héritage colonial? Mes expériences de collaboration artistique interculturelle avec des artistes et des chercheurs autochtones et non autochtones me permettront d'articuler des stratégies pédagogiques adaptées aux cours universitaires de musique d'ensembles.
(C) Canadian University Music Society / Société de musique des universités canadiennes, 2021
Ce document est protégé par la loi sur le droit d'auteur. L’utilisation des services d'Érudit (y compris la reproduction) est assujettie à sa politique d'utilisation que vous pouvez consulter en ligne.

https://apropos.erudit.org/fr/usagers/politique-dutilisation/ 


\title{
EXPANDING THE UNIVERSITY MUSIC ENSEMBLE: LESSONS FROM AN INTERCULTURAL COLLABORATION
}

\author{
D. Linda Pearse
}

\section{INTRODUCTION}

I want my non-Indigenous colleagues to take greater responsibility for exposing settler-colonialism because it is - ultimately-their story.

In response to the recommendations of Canada's Truth and Reconciliation Commission 2015 (TRC), university administrators and educators are increasingly aware of the need to re-envision curricula that engage with Indigenous perspectives, knowledge, and pedagogical approaches. Considering curricula in schools on Mi'kmaq lands, Nancy Peters notes that "school curricula have consistently failed to provide an accurate, appropriate and balanced account either of colonial history or of Aboriginal peoples' rights, issues and concerns" (Peters 2017, 151; see also Battiste 2013, 104-5). Artistic exhibits and public events have normalized and naturalized white privilege, erasing the histories of violence and oppressive social policies and practices that led to such entitlement (Peters 2017, 151-2). This failure, through the normalization of white entitlement, to account for colonial history is also visible in Canadian university music programs. ${ }^{2}$ Most music departments in Canada, particularly those focusing on European art music, use the term "music" without qualifying the

1 For a discussion of the need to listen, shoulder responsibility to decolonize, and make space for Indigenous history and experience, see Regan (2010, 190). An earlier version of this article was written for the Music and Colonialism course at McGill University, instructed by Roe-Min Kok. My collaborator Sqotewisq Judie Acquin-Miskovsky, advisor Julie Cumming, mentor Ann Waltner, and Hester Bell Jordan provided careful reading and editing support.

2 My colleague and collaborator, music theorist Robin Attas, notes that the term "music" often refers to instruction in Western art music without qualification, whereas "pop" music, and Other musics are qualified (Pearse et al. 2019). Margaret Walker identifies and deftly articulates the systemic and historical-pedagogical basis for this phenomenon (Walker 2020). Tangentially related, musicologist Tamara Levitz explores the history of the American Musicological Society and its roots as "an exclusionary, elite profession forged and maintained by white patriarchal privilege" $(2019,49)$. 
genre(s) to which it refers. The implicit assumption is that "music" is art music and that all other musics require qualification.

There are, however, several examples of music curricula at larger Canadian universities (particularly at the graduate level) that engage effectively with Indigenous content and the aims of the TRC (Memorial University n.d.; CBU n.d., "Music"; CBU n.d., "Program Details"; University of Toronto n.d., "Ethnomusicology"). We can employ a variety of theoretical and methodological frameworks to help rethink how an engagement with Indigenous knowledge at the university might trouble educational structures that sustain and further settler-colonial aims. Yet university music programs focused on the delivery of Western art music curricula still struggle to implement meaningful engagement with Indigenous knowledge that goes beyond gestures. ${ }^{3}$

The scholarly theoretical literature on Indigenization at the university far outweighs, in quantity and depth, material of a more practical nature, particularly concerning university music courses. A notable exception is Margaret Walker's project, which bridges theoretical and practical realms by advocating for a globally oriented approach to teaching core music history sequences in university music programs (Walker 2020). She articulates the importance of connecting European art music with its colonial histories, resisting the ingrained, oft repeated, and invisible impulse to consider art music within a cultural vacuum of exceptionalism. By repeatedly ignoring the embedded colonial context of European music, university music education perpetuates a racist narrative through the erasure of colonial perspectives and experiences. Yet my experience with music is primarily as a performer of European art musicmy training, understanding, and knowledge are tied intimately to practical music-making. Performance ensemble courses encompass a space that can put theoretical concepts in conversation with practical music-making.

In considering these issues, I draw on experiences from an intercultural artistic collaboration, How do we listen?, created and performed by a culturally diverse team of artists and scholars: Angela Acquin (Wolastoqew; coscript writer, speaker, educator), Hubert Francis (Mi'kmaw; singer, drummer), Sqotewisq Judie Acquin-Miskovsky (Wolastoqew; singer, drummer, educator), Wabanaki Elder J. J. Bear, Elder Brian Francis (Mi'kmaw; film maker), Ann Waltner (script writer and historian, University of Minnesota), John Watkins (speaker, University of Minnesota), and six musicians of my early European music ensemble ¡Sacabuche! (2017; for a fuller description of the project, see Pearse et al. 2019). Key themes that developed from How do we listen? have prompted me to propose pedagogical strategies for music programs at Canadian universities, with a focus on performance ensemble settings. In this article, I thus contribute pedagogical strategies for use in university music performance classes drawn from my experiences facilitating How do we listen? and grounded in theoretical literature.

3 A land acknowledgement is one example of an albeit important gesture that does not constitute meaningful engagement with Indigenous knowledge, see Vowel (2016). 
Through several years of collaborative workshops, rehearsals, performances, educational outreach, and recordings, six key themes emerged from our work on the project: the importance of place; building relationships and community; making music; embracing trust and tension; the role of elders and the importance of Indigenous leadership; and institutional barriers. Following a thick description of How do we listen? and general and theoretical considerations for music ensemble courses that engage with Indigenous knowledge, in this article I articulate practical and achievable pedagogical strategies applicable to university music ensemble classes framed by these six themes. A focus on experiential learning undergirds these strategies, manifested through connection and exchange with local Indigenous musicians. The experiences of the collaborating Mi'kmaq, Wolastoqey, and settler artists and scholars (acknowledging the great diversity of experience and identity obscured by those very terms) who created How do we listen? inspire this article. My Indigenous collaborators' expertise, opinions, stories, and words inform these strategies and framework; their feedback and approval support this writing.

\section{DESCRIPTION OF HOW DO WE LISTEN?}

It is important for us as Indigenous people to understand who we are and where we come from so that we can start the healing process. It is also important for our non-Indigenous brothers and sisters to understand what happened because we need to heal together. We share our stories in this project through music.

—Collaborators and Elders J. J. Bear and Hubert Francis 4

The intercultural artistic project How do we listen? tells the story of Angee Acquin and Sqotewisq Judie Acquin-Miskovsky, whose grandmother Virginia and sister Doris were sent to the Shubenacadie Indian Residential School (IRS) in what is known today as Nova Scotia. Doris drowned at Shubenacadie. Virginia suffered long-term effects from her experiences. Reaching from the story of the Acquin family back to the conversion to Catholicism of the Mi'kmaw Chief Membertou in 1610, this project weaves a fabric of music, soundscape, and text that converses with this culturally sensitive subject in respectful ways, drawing on historical and contemporary materials that engage with cultural identity and race.

How do we listen? was born out of tension and discomfort that occurred during the project's initial Collaborative Communities workshop (September 2017), when we layered the Mi'kmaq Honour Song with a Catholic chant. Acquin shared her grandmother's experience at Shubenacadie in response to this event and inspired the group to continue our collaborative relationship. How do we listen? employs Indigenous, early European, and newly composed music. The script incorporates Acquin's account, contemporary Indigenous poetry by

4 Email correspondence with J. J. Bear and Hubert Francis, 10 February 2019. Printed with permission. 
Rita Joe (Mi'kmaq) and Mihku Paul (Wolastoqew), historical documents, and text by historian Ann Waltner.

The project is ongoing. How do we listen? began as a workshop at Mount Allison University in Sackville, NB, in September 2017. As a group, we created a workshop documentary video (Pearse et al. 2017), secured funding through a Connection Grant from the Social Sciences and Humanities Research Council (SSHRC), and attended the SSHRC National Dialogue on Indigenous Research and Reconciliation (Ottawa, March 2019). Acquin, Waltner, Robin Attas, and I wrote a joint article describing the initial workshop and the questions it raised (Pearse et al. 2019)..$^{5}$ On 2 and 3 October 2019 we performed four outreach concerts at Leo Hayes High School in Fredericton, NB (adjacent to the Wolastoqey St. Mary's Reserve) and at Bonar Law Memorial High School in Rexton, NB (serving the Mi'kmaq populations of Elsipogtog and surrounding areas). The Leo Hayes student population is predominantly non-Indigenous (10 per cent are First Nations), whereas Bonar Law is predominantly First Nations (approximately 55 per cent). ${ }^{6}$ We premiered the complete musical-narrative work at Mount Allison University on 4 October 2019 for a public audience, with an introduction by Shubenacadie IRS survivor and Elder Dorene Bernard. Finally, we recorded a second documentary video over the course of the week (anticipated August 2020). Our artistic team aims to share our work with community and high school audiences through public performance and outreach talks supported by this second documentary video.

My own identity as a settler musician and music professor at Mount Allison figures in this project. I come from the Coast Salish region on what is now known as Vancouver Island. My intense engagement in intercultural arts and experiences living and working as a musician, foreigner, and gay woman abroad in Europe, Africa, China, and Malaysia are informed further by writings that have deepened my understanding of white privilege and what it might mean to be marginalized (Battiste 2017, 2013; Pete 2018; Bhambra et al. 2018b). Yet my experience facilitating How do we listen? laid bare a system of hegemonic power dynamics about which I had been oblivious.

I read extensively about the history, music, and culture of Mi'kmaq and Wolastoqey nations and their interactions with the government prior to the collaboration (Poliandri 2011; Knockwood 1992; Reid 1995), but despite these preparations, I discovered over and over again that the actual interface of collaboration was more volatile, more fragile, and more emotional than others I had experienced and than my theoretical reading had prepared me for. ¡Sacabuche!'s earlier projects engaged with identity, cultural collision, and encounters in the distant past. In those projects, which provide a technical and artistic foundation on which How do we listen? builds, we had told stories from the past that were relevant and fruitful for thinking about the present (see

5 Robin Attas observed the workshop as a member of the public audience. Her comments on the project sparked our further conversation and the writing of the 2019 co-authored article.

6 Email correspondence with Jennifer Horsman, teacher at Leo Hayes High School, 3 November 2019; email correspondence with Rosalie Barlow, teacher at Bonar Law Memorial High School, 5 November 2019. Printed with permission. 
Waltner et al. 2010; Pearse 2016; ¡Sacabuche! n.d.). In How do we listen? people tell their own stories about Acquin's grandmother and the intergenerational effects the Indian residential schools had on her family-stories that continue in the present.7

\section{University Music Courses: Collaborating With Indige- NOUS PARTNERS}

Exposing settler students to Indigenous perspectives, as we aimed to do in How do we listen? has the potential to create pathways of understanding and connection between settler students and Indigenous communities. It is not decolonizing in the sense expressed by Eve Tuck and K. Wayne Yang-one deeply connected to the repatriation of Indigenous land and life (Tuck and Yang 2012). ${ }^{8}$ Nevertheless, fostering a better understanding of Indigenous culture and community, and in particular the history of the IRS system and settler-colonialism, can facilitate awareness and compassion that may enable decolonizing in the future. Responding to those who see no point in engaging Indigenous perspectives in a university program that has few or no Indigenous students, Pete notes, "Decolonisation is not only designed for Indigenous peoples but has transformative potential for all people whose lives have been impacted by the limitations of white dominance" $(2018,182)$. This includes settlers whose views have been obscured and limited by settler-focused education curricula, and those that hide the history of settler-colonialism and its ongoing effects (Hess 2015, 336-8; Peters 2017, 151). My experiences in How do we listen? inspired me to consider how to expose students at my own university to similar experiences.

Mount Allison University (homepage n.d.) has taken steps recently to provide such experiences, hiring two full-time Indigenous faculty members, creating an expanded position for an Indigenous affairs coordinator, supporting Indigenous workshops and invited speakers, and providing resources for Indigenous students. Furthermore, Mount Allison has engaged with elders to help with community connections, governance, experiential learning, ceremonies, and curricular development. 9 These may be considered early steps on a longer path towards a meaningful and effective engagement with Indigenous perspectives and knowledge at the university.

Both the Mount Allison Music Department and the town of Sackville, in which the university is situated, are predominantly non-Indigenous. Of the approximately seventy Mount Allison students currently pursuing a bachelor

7 The idea that the living stories in How Do We Listen? are ongoing was pointed out to me by Ann Waltner.

8 Out of respect for Tuck and Yang's position on the overuse/misuse of the word, "decolonization" appears sparingly in this article and primarily as cited in the work of other authors. I do not consider the pedagogies suggested here to be de facto "decolonizing."

9 Email correspondence with Kim Meade, vice-president international and student affairs, Mount Allison University, 6 February 2019. The number of enrolled students was 2096 on 1 October 2018. 
of music degree, just two ( 2.8 per cent) identify as Indigenous. ${ }^{10}$ Located within the officially bilingual (French and English) province of New Brunswick, the population of Sackville is 5,331 (Statistics Canada 2019) with an ethnic origin of residents that includes just 2.4 per cent First Nations, and 1.2 per cent Metis. The mother tongue of 92 per cent of the population is English, with 8 per cent other languages and o per cent Aboriginal languages. Many of the people who identified as Indigenous for the census survey do not speak their traditional languages, as with many Indigenous peoples in Canada who lost their language as a result of the IRS and settler school systems. Thus, How do we listen? unfolds in a primarily settler anglophone population in Atlantic Canada, on Mi'kmaq and Wolastoq lands. ${ }^{11}$

As with Mount Allison, most Canadian university music curricula prioritize Western art music and position it as normative, thus obscuring and marginalizing the history and cultural relevance of other musics (Walker 2020, 13-19). Juliet Hess focuses on the interconnectedness between musics and their contexts and the centrality of music as a social practice (Hess 2015). She exposes the power dynamics inherent in approaches that prioritize the Western art tradition and criticizes those that incorporate Other materials in a tokenistic way, what she calls the "musician-as-tourist model" (339). For example, a history class might focus primarily on Western art music but include a brief unit on women in music or popular music, placing the latter two in a marginalized position compared with the normative Western art music. School music curricula therefore reinforce settler colonialism through their adherence to this structure (338).

Hess's theorization serves as a catalyst for my consideration of how one might transfer the lessons from How do we listen? to a music teaching setting. The strategies discussed below are intended to be considered within Hess's theoretical framework. Instead of the "musician-as-tourist model," I propose applying what Hess calls a "comparative music model" in ensemble performance courses in the interest of not positioning the collaboration with Indigenous musicians as a one-time event, thus marginalizing Indigenous music against a backdrop of normative Western art music (Hess 2015, 339). For example, with How do we listen? relationships were built through sustained and regular contact over an extended period of time. Transferred to a performance class context, Indigenous musicians would visit a performance course weekly or twice-monthly over the duration of a semester, employing an approach that would place different musics in conversation, situating them in relationship and in tension with each other. Frequent exchanges over a longer period of time between Indigenous musicians and performance students-in Hess's "comparative music model"-holds greater potential to disrupt the dominant Western art music paradigm than one-time tokenistic gestures (341). Crucially, universities will need to compensate Indigenous collaborators commensurate

10 Email correspondence with Stephen Runge, head of the Music Department, 22 April 2019.

11 It is my understanding that Mount Allison University is located on Mi'kmaq lands, but some rehearsals, meetings, and performances took place on Wolastoq lands. The Indigenous collaborators and elders on the project include Mi'kmaq and Wolastoq peoples. 
with other part-time instructors' salaries, a move both symbolically and materially important.

Such an approach would also expose a predominantly settler student population to different perspectives, those that include, and position relationally, the music of local Indigenous populations. Considered in counterpoint to other curricular developments, this cultural exposure would make Canada's colonial history tangible and visceral, attaching experience and sound to meaning and understanding.

\section{LEARNING FROM HOW DO WE LISTEN?}

For university ensemble directors wanting to engage with Indigenous knowledge, the experiences culled from How do we listen? suggest strategies that resonate with Hess's "comparative music model" and that problematize the institutional practices that prioritize Western art music. Below are a series of strategies to engage with local Indigenous musicians, organized by the six themes that emerged from How do we listen? For each theme, I introduce experiences from How do we listen? and then tie them to approaches for music directors and instructors of university performance courses.

\section{The Importance of Place}

The venue played a leading role in our collaboration. Universities are physical manifestations of colonial power and the infrastructure of empire (Bhambra et al. 2018a, 5). They were built and funded by the extractive savagery of colonial forces and represent in concrete, stone, and glass the history of oppression and violence enacted by settlers on Indigenous peoples and their lands. My collaborator Acquin describes her first visit to the university for the Collaborative Communities workshop: "Upon entering the university music building, I felt immediately intimidated and acutely aware of the colonial space I was entering. That feeling of intimidation goes beyond mere unfamiliarity; it is connected with feelings of inferiority and an awareness of past atrocities and their ongoing effect on my people."12

Collaborators may feel uncomfortable being on campus. Two examples from How do we listen? come to mind: Acquin and I met at a diner on the St. Mary's Reserve in Fredericton to discuss the project, and following her first visit to the university (described above), we took a walk together in the park nearby. Both the on-reserve and the off-campus locations enabled conversations that were different from those possible on-campus and helped mitigate the negative effects that the colonial space of the university had for Acquin. These examples show the effect that the venue can have on open communication between Indigenous and settler-university collaborators.

As an act of reciprocity, directors can meet with collaborators in a neutral location off-campus or one of the collaborator's choosing. Concerts can be held on-campus and on-reserve (Robinson 2012, 235-6). Bringing students out of

12 Angela Acquin, email correspondence with D. Linda Pearse, 9 July 2018. Printed with permission. 
the university and into Indigenous spaces will not only open up their imaginations but might nurture an understanding of settler-colonialism, through the discomfort and curiosity awakened by being in Indigenous space. The disconnect, friction, and difference that settler students might experience would open a path towards a heightened awareness of their settler-normative university experience. Pete notes, "Many Canadians have been structurally denied the opportunity to learn about Indigenous peoples (and also a deeper history of colonialism)" (2018, 181). Bringing settler students into Indigenous communities can take steps to correct this lack, provided that Indigenous collaborators instigate and desire the initiative. For Indigenous students, engaging with Indigenous spaces can be a way to honour their communities, cultures, and histories, aspects normally erased or ignored in settler education.

Our experience of performing How do we listen? for the predominantly First Nations audience at Bonar Law High School supports these ideas. The narrative of the script, Acquin's grandmother at Shubenacadie and the family's subsequent intergenerational trauma, became tangible, real, and concrete for both audience and performers in ways I had not anticipated. The audience was visibly moved, as demonstrated by their tears, their standing during the honour songs, the insightful questions that they posed to Acquin and Francis during the post-performance discussions, and the reactions of the Indigenous faculty and support workers at the school.

The How do we listen? presentation was amazing. I loved it and felt it offered a multi-faceted perspective on Indian Residential Schools (IRS) and also gave the students at Bonar Law Memorial High School exposure to musical art forms that they would not otherwise have the opportunity to be exposed to.... It's important to talk about IRS because even in this day and age there are many who still don't know about it. The number of people who haven't heard about IRS is shrinking but it's still important to keep teaching people about it. (Rosalie Barlow, Mi'kmaw) ${ }^{13}$

Members of the performing group, particularly those who were non-Indigenous, discussed their experiences after presenting How do we listen? at Bonar Law Memorial, noting that it changed their perception of the work and deepened their understanding of its value in intangible yet meaningful ways.

\section{Building Relationships and Community}

Experiential learning that involves being in relationship with Indigenous peoples, entering Indigenous spaces, and participating in ceremonies, teachings and on-land activities, is an undeniably rich source of learning and decentering for non-Indigenous Canadians

13 Rosalie Barlow, email correspondence with D. Linda Pearse, 21 November 2019. Printed with permission. 
Building relationships and "being in relationship" are at the heart of this work. I met Angee Acquin and Hubert Francis in September 2017 at our first "Collaborative Communities" workshop that led to a sustained artistic partnership and the creation of How do we listen? (Pearse at al. 2017). Almost two years later, we are still planning, creating, conversing, and learning. We maintain frequent contact through social media and in-person visits, mostly off-campus. The group has expanded to include musicians, scholars, a filmmaker, and elders. Behind, in between, prior to, and during these events, are sustained communication and relationship building.

In our pre-workshop conversations, Angee Acquin suggested that we begin the workshop with a talking circle and smudge ceremony. For her, the greeting time, the coming together as a community, was as important as the time spent rehearsing the music. We therefore participated in smudge ceremonies and sat in talking circles, sharing our experiences about the meaning of music in our lives, and telling jokes. These shared ceremonies and conversations came prior to performing music for, and eventually with, each other. We learned about the importance of songs for Hubert Francis, for his ancestors, and for his family of the future (for a fuller description, see Pearse et al. 2019). Similar to Beverly Diamond's discussion of the "long reach of song" at TRC events and its importance in relationship building, Francis's definition of song contrasts significantly with the idea of music being autonomous-finished the moment the last note sounds and existing on its own (in written form) separate from its social context-which is intimately tied to the Western training of ¡Sacabuche!'s musicians (Diamond 2016, 240).

This idea of the autonomous text informs the instruction of Western art music and transfers directly to the ways Western art music is conceived of, discussed, performed, learned, and taught (Bull 2019; Clarke 2013; Adorno 1976). With a few exceptions, such as jazz or popular music ensembles, university music ensembles train musicians for professional careers in the performance of Western art music. As in ¡Sacabuche!, directors prioritize efficiency of rehearsal time in an effort to perform music to the highest possible level, aiming for a unified musical approach, a musically convincing interpretation, and a clean execution of technically challenging material (Jordan 2007, 1:38, 1:53, 2005, 206; Phillips 2004, 160-4; Rudolf 1994, 331-4; Labuta 2018, 86). These practices stand in stark contrast to the values enumerated by Acquin and Francis in How do we listen?

This change from a focus on virtuosic performance to one on relationships and community was new to me and the musicians of $;$ Sacabuche! In earlier projects, we followed a strict rehearsal schedule, working as efficiently as possible in preparing music for performance. Waltner (script writer) and I created the structure of a project, chose the music, texts, and visual elements, and directed rehearsals in a hierarchical format typical of professional art music-making. Yet in her role leading the sessions, Acquin made it clear that community and a consideration of all opinions over a single person's opinion took precedent over efficiency. These activities can transform group dynamics. Since the workshop, 
all of our rehearsal phases in the How do we listen? project have started with a sharing circle and smudge ceremony.

In describing musical events at the TRC in 2015, Byron Dueck notes that musical participation was prioritized over expertise and polished performances and that this focus served participatory and community-driven goals, opening up spaces for performances of Indigenous personhood and community $(2016,272)$. Educator and researcher Nancy Peters emphasizes that listening to stories that others tell about themselves and their lives is a first step to effecting change $(2017,153)$. Dueck's and Peters's observations resonate with Acquin's tactful suggestions. A process-driven, active listening approach stands in contrast to the results-oriented focus of many Western art music ensembles and related pedagogical approaches. Many educators consider such a relational approach to be key to transforming teaching with respect to decolonization (Hess 2015, 341-2).

Therefore it is essential for the music director to set aside time to build relationships between the student ensemble members and Indigenous collaborators through conversation: the sharing of musical practices and informal performances serve not only educational purposes but also those of relationship and community building. Discussion topics can include what music means to the participants, why they play music, and their musical backgrounds. If an elder or collaborator decides to perform a smudge ceremony, students experience a powerful cultural event. Carving out time for non-performance exchange is just as important as performing for and with each other. It allows students and collaborators to build relationships and establish trust. In order to expose settler students to Indigenous music-making and culture and raise awareness of settler-colonialism and its ongoing effects on Indigenous peoples, a focus on listening, exchanging, and experiencing music in a respectful environment is a much greater priority than public performance (Turino 2008).

\section{Making Music for Each Other}

Making music for each other holds potential further to strengthen relationships, share cultural knowledge, and impart musical knowledge. Following the sharing circle and smudge ceremony during the 2017 workshop, we exchanged musical performances, taking turns playing music for each other. Francis and Acquin sang and drummed traditional Mi'kmaq and Wolastoqey songs and their respective Honour songs; ¡Sacabuche! played a sixteenth-century motet and an instrumental work (for a fuller description see Pearse et al. 2019). This activity situated us in a reciprocal and more equitable relationship, despite the colonial venue of the university auditorium.

Within the performing arts disciplines, scholars consider the dynamics of intercultural collaboration, performance aesthetics, and spaces of reconciliation and decolonization (Barney 2016; Nakata 2007). Indigenous arts scholar Dylan Robinson (Stó:lō) raises questions about the ethical and political implications of aesthetic choices in intercultural art music projects and the colonizing impulse of integration that often prioritizes settler structures, forms, and content over those of Indigenous collaborators (Robinson 2012). 
Robinson posits a three-way classification of mode of encounter: integration (dialogue or speaking over each other), musical trading or presentation (each ensemble performs their own music for the other), and a combined mode (extensive musical trading concluding with integration). He also questions the sonic positionality of the collaborators: are Indigenous voices sovereign or are they part of the supportive background? Which collaborators have to adapt more in an integrated performance? These are ethical considerations that collaborators should consider prior to performance (Robinson 2012, 235), since in collaborations with settler art-music ensembles, Indigenous musicians are often expected to conform to Western musical practices and structures: "Inclusionary performance models neo-liberal multiculturalism, wherein First Peoples are included but are not in large part involved in the creative choices of composition or presentation. While inclusionary music performance may demonstrate a sharing of space - a visual and kinetic intermingling of bodies on stage, an acoustic blending of musics, or a literary hybridization of languages - this sharing is largely premised upon a fitting of Indigenous musicians into Western paradigms of performance" (Robinson 2014, 277).

Musical trading as it occurs in How do we listen?, however, models an exchange of knowledge and positions both ensembles as equals. Thus, when Indigenous colleagues and the university ensemble wish to perform together, a model based on musical trading is a fruitful place to begin. Music directors will have conversations with collaborators about what type of music making is desired and must avoid trying to fit Indigenous music making into a piece of Western art music, particularly one that requires adaptation by Indigenous musicians to Western art paradigms and structures. A good question to ask in order to gauge the relative positioning of collaborators is, "Who is compromising their approach and to what extent?"

\section{Embracing Trust and Tension}

Tension and discomfort were essential to the creation of How do we listen? The most pronounced tension occurred in our first workshop, when we experimented with layering a Catholic chant (sung by settler contralto, Vicki St. Pierre) and the Mi'kmaq Honour Song (sung by Hubert Francis). The mixed sounds provoked a strong reaction from Acquin, who told us that both sounds together made her think of her grandmother, Virginia, who was sent to the Shubenacadie IRS (see Pearse 2017 at 08:45). What was a significant cultural mistake-layering Catholic music with the Honour Song-led to a meaningful conversation about cultural genocide by the Canadian government and its intergenerational effects on Acquin's family.

We now call this event "The Moment," as it was key in our development of trust and our desire to create the How do we listen? project (for a more in-depth discussion of "The Moment," see Pearse et al. 2019; for a consideration of the importance of tension in intercultural collaboration, see Strachan and Nickleson 2018). Our self-reflexive and reflective approach allowed this emotionally charged and potentially fraught event to become "The Moment." Our ability to deal with it was prepared by the talking circle, smudge ceremony, and musical 
exchanges that came before and were directed by Acquin and Francis. In order for real listening to happen, we needed to have achieved a level of trust. That trust blossomed under their leadership.

Being uncomfortable can be a key experience for settler students in learning about the colonial past and being able "to move from enemy to adversary to ally" (Regan 2010, 27). Similarly, Peters notes that shame can be the basis for developing empathy and a moral conscience $(2017,157) .{ }^{14}$ In a university ensemble, the music director, students, and Indigenous collaborators can create trust and a safe space for tension by carving out time for dialogue, time for listening, and time for recognizing and embracing similarity and difference. Within that cocoon of trust, discomfort and tension resulting from connecting settler students' histories with a shameful past can be productive.

For this reason, ensemble directors should establish relationships with Indigenous collaborators prior to inviting them together with their ensembles. It is essential to create a plan together with their collaborators about how the shared time will unfold. This helps ensure that the conversations unfold without a fixed idea of how things should go or what should or should not be addressed. It also enables collaborators and director to discuss and decide together on appropriate and professional honoraria. Directors should acknowledge moments of tension and discomfort as important and potentially productive events. They can contact mental and emotional health support services in preparing for and engaging in follow-up conversations with students. Elders can play an important role in guiding this process.

\section{The Role of Elders and the Importance of Indigenous Leadership}

We must rely on the elders, because they are our connection to the past, where the inherent teachings, knowledge and truths stem from. The essence of our being through the sacredness of language, song, and prayer is entrenched by spirituality, making us truly understand who we are and what we are saying.

\section{-Elder Brian Francis}

Elders are the knowledge keepers and are responsible in sharing the knowledge they carry with future generations. Even when it includes our language, ceremonies, songs, and spirituality, it is important to call on the wisdom of the elders or knowledge keepers.

-Elder J. J. Bear ${ }^{15}$

The importance and value of including and consulting with elders figured prominently in How do we listen? Our collaborating elders eased tensions, taught us about Mi'kmaq and Wolastoqey cultural history, gave language lessons and

14 Conversely, Sarah Maddison explores how the incapacity to move beyond guilt, closely related to shame, can impede a nation's ability to deal effectively with historic injustices (Maddison 2012).

15 FaceBook messenger communication with Wabanaki Elder Jerome Bear (J. J.), 28 April 2019 and Elder Brian Francis, 28 April 2019. Printed with permission. 
guidance, pointed out sensitive issues of cultural importance, solved problems, and were integral to the project. Consultation in this context goes beyond what it might mean elsewhere. Consultation means not only listening to elders but also being prepared to shift one's approach. Consultation means taking their advice even if it seems different or uncomfortable. For the music director, it is important to consult with elders about the project or curricular plan from its conception, before devising a plan for the project. As a first step, the director should contact the university Indigenous Resource Centre to review appropriate local protocols, making a plan not only for appropriate modes of communication but also for remuneration (see below for more on remuneration).

Elders and Indigenous collaborators may decide to take on leadership roles; directors need to carve out space for those roles. In How do we listen? Indigenous leadership took many forms. In addition to leading smudge ceremonies and teachings about their culture and music, Acquin, Aquin-Miskovsky, H. Francis, and Bear weighed in on most artistic aspects of the program. For example, the performance begins with Acquin speaking her account of her grandmother at the Shubenacadie IRS. The language is visceral and exposed; during rehearsals, she expressed the need to feel safe when speaking. We brainstormed and decided that bookending the text with both the Mi'kmaq and Wolastoqey Honour Songs, the former sung by Francis, and the latter by her sister Acquin-Miskovsky, would create a cocoon within which Acquin could speak her account. We then took this format to the group of musicians involved and Elders Bear and B. Francis, who collectively gave permission to incorporate the Honour Songs in this way. ${ }^{16}$

Ensemble music directors can prepare space for Indigenous leadership by being present but not dictating the terms of engagement. The classical music world, on the other hand, is accustomed to a hierarchical style of leadership in which the director makes decisions, and those below fall into line. Listening to Indigenous collaborators and being willing to adjust expectations and reframe goals serve as important touchstones.

\section{Institutional Barriers}

Among the many institutional barriers to the types of engagement I describe above are a lack of financial resources, the inflexibility of university structures and courses, faculty time constraints, a reluctance to change, and a lack of awareness among colleagues and administrators that change is necessary.

Music directors should remunerate Indigenous collaborators and elders with gifts and mutually-agreed-upon professional honoraria. "Finding ways to include Indigenous voices and perspectives respectfully without burdening Indigenous peoples is a balance to be considered" (Davis et al. 2017, 407). The TRC Calls to Action under the rubric "Education for Reconciliation" call upon the Canadian governments to "provide the necessary funding to post-secondary

16 How to seek permission is a complex topic of considerable depth that goes beyond the scope of this article. Universities provide guidelines on the ethics and methods of seeking permission which may serve as a resource for the instructor. 
institutions to educate teachers on how to integrate Indigenous knowledge and teaching methods in classrooms" and on the Council of Ministers of Education to maintain a commitment to "building student capacity for intercultural understanding, empathy, and mutual respect" (Truth and Reconciliation Commission of Canada 2015b, 62. ii. and 63. iii., 7). The mandate is there: educators need to request financial support or decide to reallocate funding from other streams. In addition, the director should provide gifts (e.g., tobacco or sweet grass) to honour their contributions.

Ensemble curricula and course structures will require revamping. Curricula that "designate Western classical music as the most worthy of study" through an emphasis on Western music and musical approaches can be adjusted to reflect a relational model of instruction that includes Other musics, rebalancing the dynamics that position Western classical music as normative (Hess 2015, 336, 345). ${ }^{17}$ Applying a relational pedagogy means that there will be less time to focus on the preparation and performance of Western art music. Performances may need to be shortened. Ensemble directors might resist such changes because the ensemble will inevitably cover a smaller repertoire in a semester.

Beyond funding and curricular constraints, the time and will of directors to undertake this type of engagement are essential. This work requires careful planning, a willingness to be wrong and to change, the ability to learn from discomfort, and a genuine desire to question the very habits and foundation upon which their training and professional lives rest. The success of a relational approach to ensemble performance pedagogy depends on educators' will to crack that burnished veneer of settler privilege and let light in, bringing Indigenous cultural knowledge into conversation with normative settler-colonial cultural narratives in an equal way.

\section{Conclusion}

My Indigenous collaborators recognize and reiterate the need for meaningful change, particularly in educational settings. The perspectives of settler scholars who recognize the need for advocacy, responsibility, and action will form an important part of this change (Regan 2010; Peters 2017; Battell Lowman and Barker 2015). Education is regarded as "perhaps the most insidious ... of colonialist survivals," particularly in the ways in which it serves as a legal and administrative apparatus of colonialism and perpetuates colonial ideologies into the present and foreseeable future, shaping not only the content imbibed by its students, but more importantly, the latter's thinking and ideology (Ashcroft et al. 2006; see also Pete 2018; Bhambra et al. 2018a; Battiste 2013, 2017; Peters 2017). By drawing on Indigenous knowledge and community-centred practices, scholars and pedagogues can advocate for a reimagined university education system, direct a restructuring of the mammoth colonial and neo-colonial

17 Hess considers primarily elementary school programs. In middle and high school programs, there is often an emphasis placed on jazz music in addition to Western classical music. At the university level there are also examples of popular, jazz, and other musics figuring prominently in music curricula. 
machine, and promote a model for comparative education that prioritizes relational pedagogical strategies, an engagement with local Indigenous cultural knowledge, cultural responsivity, and self-reflective instructor practices (Ashcroft et al. 2006; Archibald 2008; Battiste 2005, 2013, 2017; Bhambra et al. 2018a; Crossley and Tikly 2004; Morgensen 2012; Pio et al. 2014; Pirbhai-Illich et al. 2017; Regan 2010; Styres 2017; Altbach 2006).

Meaningfully collaborating with Indigenous elders and musicians as part of university music ensembles and allowing them to set the pace and terms of engagement is a profound way to engage with the calls to action of the Truth and Reconciliation Commission. We must not only invite Indigenous knowledge-holders into university-settler spaces, but also build relationships that allow reciprocation and engagement in Indigenous spaces and on Indigenous terms. Those Calls to Action were never going come without costs, material and non-material, including time, commitment, intellectual territories, and financial support (see Bierman 2011,394). But the costs involved in the proposed approach to ensemble courses have the potential to create communities where settler music students learn to share and respect Indigenous knowledge and where Indigenous students are made more visible through respectful acknowledgement of and engagement with their cultural practices by settler institutions. Shauneen Pete's call for her "non-Indigenous colleagues to take greater responsibility" resounds here (Pete 2018, 180). If the How do we listen? project is any indication, it's worth it.

\section{REFERENCES}

Acadia University School of Music. "About Us.” https://music.acadiau.ca/ about-us.html.

Adorno, Theodor W. 1976. "Funtion." In Introduction to the Sociology of Music, 39-54. New York: Seabury.

Altbach, Philip. 2006. "Education and Neocolonialism." In The Post-Colonial Studies Reader, 2nd ed., edited by Bill Ashcroft, Gareth Griffiths, and Helen Tiffin, 381-84. London: Routledge, Taylor \& Francis Group.

Archibald, Jo-Ann. 2008. Indigenous Storywork: Educating the Heart, Mind, Body, and Spirit. Vancouver: UBC Press.

Ashcroft, Bill, Gareth Griffiths, and Helen Tiffin, eds. 2006. The Post-Colonial Studies Reader. 2nd ed. London: Routledge, Taylor \& Francis Group.

Barney, Katelyn. 2016. "At the Contact Zone and the Cultural Interface: Theorising Collaboration between Indigenous and Non-Indigenous People in Research and Contemporary Music Practices." In The Routledge International Handbook of Intercultural Arts Research, edited by Pamela Burnard, Elizabeth Mackinlay, and Kimberly Anne Powell, 102-14. London: Routledge, Taylor \& Francis Group.

Battell Lowman, Emma, and Adam J. Barker. 2015. Settler: Identity and Colonialism in 21st-Century Canada. Halifax: Fernwood Publishing.

Battiste, Marie. 2005. "Post-Colonial Remedies for Protecting Indigenous Knowledge and Heritage." In Teaching as Activism, edited by Peggy Tripp and Linda Muzzin, 224-32. Equity Meets Environmentalism. Montreal 
and Kingston: McGill-Queen's University Press. http://www.jstor.org/ stable/j.ctt7zrhs.22.

. 2013. Decolonizing Education: Nourishing the Learning Spirit. Repr. Saskatoon: Purich Publishing.

-2017. Visioning a Mi'kmaw Humanities: Indigenizing the Academy. Sydney, NS: Cape Breton University Press.

Bhambra, Gurminder K., Dalia Gebrial, and Kerem Nişancığlu, eds. 2018a. Decolonizing the University. Repr. London: Pluto.

_. 2018b. "Introduction: Decolonising the University?" In Decolonizing the University, edited by Bhambra, Gebrial and Nişancıoğlu. Repr. London: Pluto.

Biermann, Soenke. 2011. "Knowledge, Power and Decolonization: Implication for Non-Indigenous Scholars, Researchers and Educators." Counterpoints 379:386-98.

Bull, Anna. Class, Control, and Classical Music. New York: Oxford University Press, 2019.

CBU. n.d. "CBU Program Details." Accessed 29 April 2019. https://www.cbu. ca/academic-programs/program/music/program-details/.

CBU. n.d. "Music." https://www.cbu.ca/academic-programs/program/music/.

Clarke, D. 2013. "Music Autonomy Revisited." In The Cultural Study of Music: A Critical Edition, edited by Martin Clayton, Trevor Herbert, and Richard Middleton, 172-83. New York: Routledge.

Crossley, Michael, and Leon Tikly. 2004. "Postcolonial Perspectives and Comparative and International Research in Education: A Critical Introduction." Comparative Education 40 (2): 147-56.

Davis, Lynne, Chris Hiller, Cherylanne James, Kristen Lloyd, Tessa Nasca, and Sara Taylor. 2017. "Complicated Pathways: Settler Canadians Learning to Re/Frame Themselves and Their Relationships with Indigenous Peoples." Settler Colonial Studies 7 (4): 398-414. https://doi.org/10.1080/22 01473 X.2016.1243086.

Diamond, Beverly. 2016. "The Long Reach of Song at the Truth and Reconciliation Commission on Indian Residential Schools." In Arts of Engagement: Taking Aesthetic Action in and Beyond the Truth and Reconciliation Commission of Canada, edited by Dylan Robinson and Keavy Martin, 239-66. Indigenous Studies Series. Waterloo, ON: Wilfrid Laurier University Press.

Dueck, Byron. 2016. "Song, Participation, and Intimacy at the Truth and Reconciliation Gatherings." In Arts of Engagement: Taking Aesthetic Action in and Beyond the Truth and Reconciliation Commission of Canada, edited by Dylan Robinson and Keavy Martin, 267-82. Indigenous Studies Series. Waterloo, ON: Wilfrid Laurier University Press.

Hess, Juliet. 2015. "Decolonizing Music Education: Moving beyond Tokenism." International Journal of Music Education 33 (3): 336-47. https://doi. org/10.1177/0255761415581283.

Jordan, James Mark. 2005. The Choral Warm-Up:Method, Procedures, Planning, and Core VocalExercises. EvokingSound.Chicago:GIAPublications.https:// www.giamusic.com/store/resource/the-choral-warmup-book-g6397. 
-2007. The Choral Rehearsal: Techniques and Procedures. Vol. 1. Evoking Sound. Chicago: GIA Publications.

Knockwood, Isabelle. 1992. Out of the Depths: The Experiences of Mi'kmaw Children at the Indian Residential School at Shubenacadie, Nova Scotia. 2nd ed. Lockeport, NS: Chelsea Green Publishing.

Labuta, Joseph A. 2018. Basic Conducting Techniques. 7th ed. New York: Routledge.

Laurentian University. n.d. "Music, Program Details." https://laurentian.ca/ program/music/details.

Levitz, Tamara. 2019. “The Musicological Elite.” Current Musicology 102 (2018): 9-80.

Maddison, Sarah. 2012. "Postcolonial Guilt and National Identity: Historical Injustice and the Australian Settler State." Social Identities 18 (6): 695-709.

Memorial University. n.d. "M.A. and Ph.D. Ethnomusicology." https://www. mun.ca/music/programs/ethno.

—. n.d. "Memorial School of Music." Accessed 29 April 2019. https://www. mun.ca/music/.

Mohanty, Chandra Talpade. 2003. Feminism without Borders: Decolonizing Theory, Practicing Solidarity. Durham, NC: Duke University Press.

Morgensen, Scott Lauria. 2012. "Destabilizing the Settler Academy: The Decolonial Effects of Indigenous Methodologies." American Quarterly 64 (4): $805-8$.

Mount Allison University. n.d. "Full and Part-time Faculty." https://www.mta. ca/Community/Academics/Faculty of_Arts/Music/Faculty and staff/ Faculty__staff/.

.n.d. "Homepage." https://www.mta.ca/Prospective/Default.aspx.

-n.d. "Music." https://www.mta.ca/music/.

Nakata, Martin. 2007. "The Cultural Interface." Australian Journal of Indigenous Education 36, no. S1 (2007): S7-14.

Pearse, D. Linda. 2016. Matteo Ricci: His Map and Music. San Francisco, CA: Direct Light Studios. The Ricci Institute for Chinese-Western Cultural History, University of San Francisco. https://www.youtube.com/ watch? $\mathrm{v}=$ FLXojsLy8I8\& $\mathrm{t}=528 \mathrm{~s}$.

Pearse, D. Linda, Angela Acquin, Robin Attas, and Ann Waltner. 2019. "Unpacking a Moment: Decolonization in the Performing Arts?" MUSICultures 46 (1): 1-31.

Pearse, D. Linda, Angela Acquin, and Ann Waltner. 2017. Collaborative Communities: Indigenous and Non-Indigenous Artists and Scholars. Sackville, NB: Améri Ka Productions. https://www.youtube.com/ watch? $=$ =FjVKx-G3udg.

Pete, Shauneen. 2018. "Meschachakanis, a Coyote Narrative: Decolonising Higher Education." In Decolonizing the University, edited by Gurminder K. Bhambra, Dalia Gebrial, and Kerem Nişancioğlu, 173-89. Repr. London: Pluto.

Peters, Nancy. 2017. "Learning Shame: Colonial Narratives as a Tool for Decolonization." In Visioning a Mi'kmaw Humanities: Indigenizing the 
Academy, edited by Marie Battiste, 149-64. Sydney, NS: Cape Breton University Press.

Phillips, Kenneth H. 2004. Directing the Choral Music Program. New York: Oxford University Press.

Pio, Edwina, Kitea Tipuna, Ali Rasheed, and Lorraine Parker. 2014. "Te Werothe Challenge: Reimagining Universities from an Indigenous World View." Higher Education 67 (5): 675-90.

Pirbhai-Illich, Fatima, Shauneen Pete, and Fran Martin. 2017. Culturally Responsive Pedagogy: Working towards Decolonization, Indigeneity and Interculturalism. Cham, Switzerland: Springer.

Poliandri, Simone. 2011. First Nations, Identity, and Reserve Life: The Mi'kmaq of Nova Scotia. Lincoln: University of Nebraska Press.

Regan, Paulette. 2010. Unsettling the Settler Within: Indian Residential Schools, Truth Telling, and Reconciliation in Canada. Vancouver: University of British Columbia Press. http://www.deslibris.ca/ID/44019o.

Reid, Jennifer. 1995. Myth, Symbol, and Colonial Encounter: British and Mi'kmaq in Acadia, 1700-1867. Ottawa: University of Ottawa Press.

Robinson, Dylan. 2012. "Listening to the Politics of Aesthetics: Contemporary Encounters between First Nations/Inuit and Early Music Traditions." In Aboriginal Music in Contemporary Canada, edited by Beverly Diamond and Anna Hoefnagels, 222-48. Montreal and Kingston: McGill-Queen's University Press.

_. 2014. "Feeling Reconciliation, Remaining Settled." In Theatres of Affect, edited by Erin Hurley, 275-306. Vol. 4. New Essays on Canadian Theatre. Toronto: Playwrights Canada Press.

Rudolf, Max. 1994. The Grammar of Conducting: A Comprehensive Guide to Baton Technique and Interpretation. New York: Schirmer Books.

¡Sacabuche! n.d. “¡Sacabuche!” https://sacabuche.com/.

Statistics Canada. 2019. "Census Profile, 2016 Census." https://www12. statcan.gc.ca/census-recensement/2016/dp-pd/prof/details/page.cf$\underline{\mathrm{m}}$ ? Lang $=\mathrm{E} \& \mathrm{Ge} 01=\mathrm{CSD} \& \mathrm{Code} 1=1307009 \& \mathrm{Ge} 02=\mathrm{PR} \& \mathrm{Code}_{2}=13 \&$ $\underline{D a t a}=$ Count $\&$ SearchText $=$ Sackville $\&$ SearchType $=$ Begins $\&$ Search -

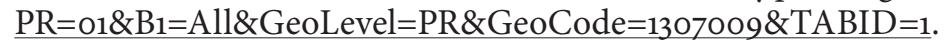

Strachan, Jeremy, and Patrick Nickleson. 2018. "Doing Long Work: Critical Perspectives on Indigenous-Settler Collaboration in Canadian Art Music." University of Toronto Quarterly 87 (4): 83-101. https://doi.org/10.3138/ utq.87.4.10.

Styres, Sandra D. 2017. Pathways for Remembering and Recognizing Indigenous Thought in Education: Philosophies of Iethi'nihsténha Ohwentsia'kékha (Land). Toronto: University of Toronto Press.

Truth and Reconciliation Commission of Canada. 2015a. Honouring the Truth, Reconciling for the Future: Summary of the Final Report of the Truth and Reconciliation Commission of Canada. Winnipeg, MB: Truth and Reconciliation Commission of Canada. http://www.deslibris.ca/ID/218849.

- 2015b. Honouring the Truth, Reconciling for the Future: Summary of the Final Report of the Truth and Reconciliation Commission of Canada. Calls 
to Action. Winnipeg, MB: Truth and Reconciliation Commission of Canada. http://nctr.ca/reports.php.

Tuck, Eve, and K. Wayne Yang. 2012. "Decolonization Is Not a Metaphor." Decolonization: Indigeneity, Education \& Society 1 (1): 1-40.

Turino, Thomas. 2008. Music as Social Life: The Politics of Participation. Chicago: University of Chicago Press.

University of Prince Edward Island. "Department of Music | Faculty of Arts | UPEI." n.d. Accessed 29 April 2019. https://www.upei.ca/arts/music.

University of Toronto. n.d. "Ethnomusicology." https://music.utoronto.ca/ areas-of-study.php?asID $=5$.

Vowel, Chelsea. 2016. "Beyond Territorial Acknowledgments." Âpihtawikosisân (blog), 23 September. https://apihtawikosisan.com/2016/og/ beyond-territorial-acknowledgments/.

Walker, Margaret. 2020. "Towards a Decolonized Music History Curriculum." In "Decolonization." Special issue, Journal of Music History Pedagogy, 10 (1): 1-19.

Waltner, Ann, Qin Fang, and D. Linda Pearse. 2010. "The Map and Music of Matteo Ricci." Ming Studies 62: 1-24.

\begin{abstract}
Universities are increasingly aware of the need to re-envision curricula in order to engage with Indigenous perspectives, knowledge, and pedagogical approaches. University music programs, focused on the delivery of Western art music curricula, often struggle to implement meaningful engagement with Indigenous knowledge that goes beyond gestures. What practical steps can educators take to crack the seemingly impervious fabric of settler-colonial art music performance education? I draw on experiences from within an intercultural artistic collaboration of Indigenous and non-Indigenous artists and scholars in order to articulate pedagogical strategies applicable to university music performance ensemble classes.
\end{abstract}

\title{
RÉSUMÉ
}

Les universités sont de plus en plus conscientes de la nécessité de revoir les programmes d'études afin de prendre en compte les perspectives, les connaissances et les approches pédagogiques autochtones. Les programmes universitaires en musique, axés sur l'enseignement du corpus de musiques occidentales savantes, ont souvent du mal à mettre en œuvre un engagement réel et significatif avec les connaissances autochtones. Quelles mesures concrètes les enseignants peuvent-ils prendre pour aller au-delà de l'enseignement du canon limité par l'héritage colonial? Mes expériences de collaboration artistique interculturelle avec des artistes et des chercheurs autochtones et non autochtones me permettront d'articuler des stratégies pédagogiques adaptées aux cours universitaires de musique d'ensembles. 


\section{BIOGRAPHY}

D. Linda Pearse is associate professor of music at Mount Allison University and adjunct lecturer at Indiana University Bloomington. She is the artistic director of the San Francisco Early Music Summer Baroque Workshop, the Sackville Festival of Early Music, and the chamber music ensemble ¡Sacabuche! Her research focuses on intercultural encounters and collisions in the early modern period. She creates artistic works that combine text, soundscape, and music to tell complex stories. 